\title{
Sustainable Development Approaches in the New Law of the Sea
}

\author{
Nathalie ROS ${ }^{*}$
}

Abstract: Due to the emergence of sustainable development and in relation with the Law of the Sea, a new set of principles and rules has emerged at the crossroads of LOSC and the CBD; it defines a renewed legal framework (A), especially in terms of rights and obligations of coastal states over maritime spaces and marine resources, but also of environmental protection and preservation. This new approach supposes, for example, to be able to strike a balance between exploitation of marine resources and protection of marine biodiversity, and is at the core of current challenges of economic exploitation (B), both in the superjacent waters and on the seabed and subsoil.

Keywords: Sustainable development - Law of the Sea - LOSC - CBD - coastal state - marine environment marine biodiversity - marine resources - economic exploitation

\section{INTRODUCTION}

The matter of the Chagos Marine Protected Area Arbitration, between Mauritius and United Kingdom, which was decided on I8 March 2015, is a very relevant case in order to illustrate the importance and pertinence of sustainable development approaches in the new Law of the Sea.

The case opposed Mauritius, a developing country, and furthermore a Small Island Developing State, to its former colonizer, United Kingdom, about a part of the national territory, the Chagos Archipelago, and the right of their inhabitants to live in their native islands. United Kingdom had detached the Chagos Archipelago from the colony in 1965, before the independence of Mauritius in 1968, and had then administrated it as the British Indian Ocean Territory (BIOT) in order for the Diego Garcia Island to become a United States military base. ${ }^{2}$ The detachment was realized under conditions, including fishing rights of native population, reversion to Mauritius of the benefit of any minerals or oil discovered in or near the Chagos Archipelago, and above all the UK's undertaking that if the need for defence purposes disappeared the islands should be returned to Mauritius. But,

\footnotetext{
* Professor at the University François Rabelais of Tours (LERAP) - France, Vice-Chair \& Secretary-General of the International Association of the Law of the Sea.

I Permanent Court of Arbitration, Award, I8 March 2015, Chagos Marine Protected Area Arbitration (Mauritius v. United Kingdom).

2 A. Oraison, 'À propos du litige anglo-mauricien sur l'archipel des Chagos (La succession d'États sur les îles Diego Garcia, Peros Banhos et Salomon)', Revue belge de droit international (1990) 5-53; 'Diego Garcia: enjeux de la présence américaine dans l'océan Indien', Afrique contemporaine (2003) II5-I32 [DOI: I0.3917/afco.207.0II5]; 'Histoire et actualité de la base militaire de Diego Garcia. Les circonstances de la création et de la militarisation du British Indian Ocean Territory (BIOT)', Outre-mers (2005) 27I-289 [DOI: 10.3406/outre.2005.4173]. The US military base of Diego Garcia had been granted to the United States in 1966 for a period of 50 years, which could be extended by 20 years, and the territory could therefore have been returned in 2016. On 16 November 2016, the concession was finally renewed and should therefore last until 30 December 2036.
} 
between 1968 and 1973, the United Kingdom proceeded to remove the Chagossian population from the Archipelago; since then, deported Chagossians unsuccessfully attempted to assert their rights to return and live in their native islands. ${ }^{3}$

The dispute between the Parties concerned a decision of the United Kingdom, taken on I April 20Io, by which it established a large no-take Marine Protected Area around the Chagos Archipelago, ${ }^{4}$ using environmental concerns as a pretext to assert territorial jurisdiction against the interests of a Small Island Developing State and the right of abode of native populations, depriving them of their economic livelihood, 5 as was revealed by a WikiLeaks cable. ${ }^{6}$ But the Arbitral Tribunal, constituted under LOSC, has confirmed the legally binding character of the conditions stated in 1965, especially the United Kingdom's undertaking to return the Chagos Archipelago to Mauritius, when no longer needed for defence purposes; moreover, it has declared that, in establishing the MPA surrounding the Chagos Archipelago, the United Kingdom breached its obligations under the Law of the Sea Convention.7

De facto, the Chagos dispute appears a case study: it recalls the indivisibility and interdependence of the three dimensions of sustainable development, and underlines that environmental concerns cannot be opposed to social and economic preoccupations. On the contrary, they have to be balanced and implemented jointly, and this is also an essential requirement in the new Law of the Sea, as evidenced by recent developments within the United Nations. The Sixteenth meeting of the United Nations Open-ended Informal Consultative Process on Oceans and the Law of the Sea, held in April 20I5, was precisely dedicated to Oceans and sustainable development: integration of the three dimensions

3 The Decision of the European Court of Human Rights, of II December 20I2, has rejected the application in the case Chagos Islanders against the United Kingdom; on 29 June 2016, the Supreme Court ruled against setting aside the 2008 Lords verdict on the lawfulness of the 2004 Orders abolishing the right to return, but this judgment may have opened the way to a legal challenge to the ban on resettlement. Cf. C. Alexandre \& K. Koutouki, 'Les déplacés des Chagos. Retour sur la lutte de ces habitants pour récupérer leur terre ancestrale', Revue québécoise de droit international (20I4) I-26; R. Le Mestre, 'L'archipel du chagrin ou la lutte des habitants des îles Chagos pour gagner un droit au retour sur leur terre', Annuaire de Droit Maritime et Océanique (2010) 197-227; J. Lunn, 'Disputes over the British Indian Ocean Territory: December 2016 update', House of Commons Library, Briefing Paper Number 6908, I December 2016.

4 Proclamation $\mathrm{N}^{\circ}$ I of 2010.

5 E.M. De Santo, P.J.S. Jones, A.M.M. Miller, 'Fortress conservation at sea: a commentary on the Chagos MPA', Marine Policy (20II) 258-260 [DOI:I0.I0I6/j.marpol.2010.09.004]; N. Monebhurrun, 'Creating Marine Protected Areas to assert territorial jurisdiction against the Right of Abode of Native Populations: The Case of the Chagos Archipelago', in C. Cinelli \& E.M. Vásquez Gómez (Ed.), Regional Strategies to Maritime Security: a Comparative Perspective, MARSAFENET (Tirant lo Blanch, Valencia, 2014) 79-99; P. Sand, 'The Chagos Archipelago - Footprint of Empire, or World Heritage?', Environmental Policy and Law (2010) 232-242; 'The Chagos Archipelago Cases: Nature Conservation Between Human Rights and Power Politics', The Global Community Yearbook of International Law o J Jurisprudence (2013) I25-150.

6 HMG Floats Proposal for Marine Reserve Covering the Chagos Archipelago (British Indian Ocean Territory), Date: 2009 May 15, 07:00 (Friday), Canonical ID: o9LONDONis56_a.

7 "B. In relation to the merits of the Parties' dispute, the Tribunal, having found, inter alia, (I) that the United Kingdom's undertaking to ensure that fishing rights in the Chagos Archipelago would remain available to Mauritius as far as practicable is legally binding insofar as it relates to the territorial sea; (2) that the United Kingdom's undertaking to return the Chagos Archipelago to Mauritius when no longer needed for defence purposes is legally binding; and (3) that the United Kingdom's undertaking to preserve the benefit of any minerals or oil discovered in or near the Chagos Archipelago for Mauritius is legally binding; DECLARES, unanimously, that in establishing the MPA surrounding the Chagos Archipelago the United Kingdom breached its obligations under Articles 2(3), 56(2), and 194(4) of the Convention”; Arbitral Award, I8 March 2015, Chapter VIII - Dispositif, at 215, $\$ 547$. 
of sustainable development, namely, environmental, social and economic. ${ }^{8}$ In the same way, the UN 2030 Agenda for Sustainable Development, adopted by the General Assembly on 25 September 2015, identified a Sustainable Development Goal I4 (SDG I4), 9 especially dedicated to Life below water and named Conserve and sustainably use the oceans, seas and marine resources for sustainable development, ${ }^{\text {IO }}$ as one of the 17 Sustainable Development Goals and as part of a highly inter-connected agenda including nine other goals supposed to be closely linked with oceans and seas. ${ }^{\text {II }}$

Actually, progressive emergence of sustainable development has implied a new legal approach, linking development and environmental concerns. ${ }^{\mathrm{I2}}$ In relation with the Law of the Sea, a new set of principles and rules has emerged at the crossroads of LOSC and the Convention on Biological Diversity, defining a renewed legal framework (A), especially in terms of rights and obligations of coastal states over maritime spaces and marine resources, but also of environmental protection and preservation. This new approach of the Law of the Sea supposes, for example, to be able to strike a balance between exploitation of marine resources and protection of marine biodiversity, and is at the core of current challenges of economic exploitation (B), both in the superjacent waters and on the seabed and subsoil. The new Law of the Sea as a whole is concerned, from sustainable management of fisheries to IUU fishing, from biodiversity beyond national jurisdiction to offshore exploitation and deep-sea mining in the Area.

Sustainable development approaches are all new stakes for the future of the Law of the Sea, not only in the perspective of possible negotiations, but also in terms of effectivity and governance of oceans and seas.

\section{(A) A RENEWED LEGAL FRAMEWORK}

International Law, and especially International Law of the Sea, forms the legal framework for global sustainable development; but conversely, requirements of sustainable development contribute to define the new conceptual dimensions (I) that characterize its current legal approaches (2).

\section{(I) New Conceptual Dimensions}

Thoroughly linked with development issues, the emergence of sustainable development (a) has shown at once an ontological relationship with the Law of the Sea (b).

\section{(a) Emergence of Sustainable Development}

Both developmental needs and environmental preoccupations are at the origins of sustainable

8 Sixteenth meeting of the UN Open-ended Informal Consultative Process on Oceans and the Law of the Sea.

9 A United Nations Conference to Support the Implementation of SDG I4 will be convened at the UN Headquarters from 5 to 9 June 2017 .

Io Sustainable Development Goal 14.

II Poverty eradication (SDG I), food security and sustainable agriculture (SDG 2), health (SDG 3), clean water and sanitation (SDG 6), modern energy (SDG 7), growth and employment (SDG 8), climate (SDG I3), ecosystems and biodiversity (SDG 15) and partnerships (SDG 17).

I2 A. Aranha Corrêa do Lago, Conferências de desenvolvimento sustentável (FUNAG, Brasília, 20I3). 
development (i); based on a triple dimension, the definition of sustainable development (ii) conceptually reflects this ontological approach.

\section{(i) Origins of Sustainable Development}

International Law of Development appeared in the 1960's, characterized by an ideological dimension, linking development and decolonization, international cooperation and economic development. ${ }^{\mathrm{I} 3}$ But during the 1970's, a new concept seemed emerging, destined to completely change the conception and philosophy of development, integrating a comprehensive approach, together ecological, economic and social: the concept of sustainable development. . $^{4}$

Environmental awareness is a relatively recent preoccupation; ${ }^{15}$ it is contemporaneous of the end of the last century and especially of the 1970's, with the United Nations Conference on the Human Environment, having met at Stockholm from 5 to 16 June 1972. This first environmental conference created the United Nations Environment Programme (UNEP), to work in close relation with the United Nations Development Programme (UNDP) established in 1966. It also adopted the Stockholm Declaration, ${ }^{16}$ a soft law contribution, encompassing twenty-six principles; combining economic and social development and preservation and improvement of human environment, it is a step forward towards the future emergence of sustainable development. ${ }^{17}$

The expression was first employed in 1980 by IUCN, the International Union for Conservation of Nature, in its report World Conservation Strategy: Living Resource Conservation for Sustainable Development, ${ }^{18}$ and then officially in 1983 in the General Assembly Resolution creating the World Commission on Environment and Development, ${ }^{19}$ known as the Brundtland Commission after its Chairman, the Norwegian Prime Minister Gro Harlem Brundtland, after the failure of the Nairobi Conference in May 1982. The report of this Commission was published in 1987; it is entitled Our Common Future, and is famous for its Chapter 2 Towards sustainable development, popularizing the expression and concept. ${ }^{20}$

De facto, the Brundtland Report is an essential source of inspiration for the United Nations Conference on Environment and Development (UNCED), held in Rio de Janeiro from 3 to I4 June 1992, which led to the adoption of five documents: two international conventions (the Convention on Biological Diversity and the Convention on Climate Change) and three soft law instruments, the Statement of Principles on Forests, the Rio Declaration and the International Action Plan Agenda 2I,

\footnotetext{
I3 G. Feuer \& H. Cassan, Droit international du développement (Dalloz, Paris, 1985).

I4 On the origins of the concept, J-G. Vaillancourt, 'Action 2I et le développement durable', VertigO - la revue électronique en sciences de l'environnement, Volume 3, Numéro 3, décembre 2002, § I-IO [DOI: I0.4000/vertigo.4I72].

is J. Juste Ruiz, 'L'evolució del dret internacional del medi ambient', Autonomíes, núm I5, desembre de I992, Barcelona, $45-57$.

16 Declaration of the United Nations Conference on the Human Environment.

17 A.Ch. Kiss \& J-D. Sicault, 'La Conférence des Nations Unies sur l'environnement (Stockholm, 5/16 juin 1972)', Annuaire français de droit international (1972) 603-628 [DOI: 10.3406/afdi.1972.1717].

i8 World Conservation Strategy: Living Resource Conservation for Sustainable Development.

is United Nations General Assembly, Resolution 38/16I Process of preparation of the Environmental Perspective to the Year 2000 and Beyond, 19 December 1983.

20 Our Common Future.
} 
which both enshrine the concept of sustainable development.

The Rio Declaration on Environment and Development states twenty-seven principles setting forth the philosophy of sustainable development, twelve of which expressly refer to it. ${ }^{21}$ As a starting point, Principle I specifies that "Human beings are at the centre of concerns for sustainable development". "Development of international law in the field of sustainable development" is one of the objectives set by Principe 27 and directly refers to the definition of sustainable development.

\section{(ii)Definition of Sustainable Development}

The first definition of sustainable development is given by the Brundtland Report; it is probably still the best and simplest formula to understand the concept: "Sustainable development is development that meets the needs of the present without compromising the ability of future generations to meet their own needs". ${ }^{22}$

From the vantage point of International Law, and notwithstanding doctrinal controversies on the legal value of the concept of sustainable development, ${ }^{23}$ the International Court of Justice has underlined that the "need to reconcile economic development with protection of the environment is aptly expressed in the concept of sustainable development", pursuant to its Judgment of 25 September 1997, in the case concerning the Gabcikovo-Nagymaros Project (Hungary/Slovakia).24 In its Order of 13 July 2006, in the case concerning Pulp Mills on the River Uruguay (Argentina v. Uruguay), the Court has also highlighted "the importance of the need to ensure environmental protection of shared natural resources while allowing for sustainable economic development ${ }^{25}$ Both arbitral jurisprudence ${ }^{26}$ and WTO Appellate Body and Panels decisions confirm this approach, ${ }^{27}$ and the conception developed by international case law thus perfectly fits with Principle 4 of the Rio Declaration: "In order to achieve sustainable development, environmental protection shall constitute an integral part of the development process and cannot be considered in isolation from it".

From the perspective of International Law, sustainable development has to be understood not only according to its three essential dimensions, namely, environmental, social and economic, but also to a double approach, both spatial and temporal.

2I Principles I, 4, 5, 7, 8, 9, I2, 20, 2I, 22, 24 and 27.

${ }_{22}$ The whole definition reads as follows: "Sustainable development is development that meets the needs of the present without compromising the ability of future generations to meet their own needs. It contains within it two key concepts: the concept of 'needs', in particular the essential needs of the world's poor, to which overriding priority should be given; and the idea of limitations imposed by the state of technology and social organization on the environment's ability to meet present and future needs".

23 For a recent analysis, V. Barral, 'Sustainable Development in International Law: Nature and Operation of an Evolutive Legal Norm', European Journal of International Law (2012) 377-400 [DOI:Io.Io93/ejil/chsor6].

24 ICJ Reports 1997, at 78, $\$$ I40.

25 ICJ Reports 2006, at I33, $\$ 80$.

26 See, for example, and by direct reference to the Judgment of the Court in the Gabcikovo-Nagymaros case, Award in the Arbitration regarding the Iron Rbine ("Ijzeren Rijn") Railway between the Kingdom of Belgium and the Kingdom of the Netherlands, Decision of 24 May 2005, RIAA, Volume XXVII 2008, at 66-67, $\$ 59$.

${ }_{27} \mathrm{Ph}$. Sands, 'International Courts and the Application of the Concept of "Sustainable Development", Max Planck Yearbook of United Nations Law (1999) 389-405; D. Luff, 'An Overview of International Law of Sustainable Development and a Confrontation between WTO Rules and Sustainable Development', Revue belge de droit international (I996) 9I-I44. 
The spatial logic of the concept refers to development, in the global context of disparities still shown by North-South relations, and imposes the need to resolve current conflicts of interests between industrialized countries, now conscious of the ecological future of the planet, and developing countries, primarily concerned about their own economic development.

The temporal logic of the concept refers to sustainability and imposes an intergenerational approach so that the immediate needs of the present generation will not compromise the future of forthcoming generations.

Both approaches appear interdependent and indivisible in International Law, as required by Principle 3 of Rio: "The right to development must be fulfilled so as to equitably meet developmental and environmental needs of present and future generations", as perfectly reflected by the relationship with the Law of the Sea.

\section{(b) Relationship with the Law of the Sea}

In 1972, Principle 7 of the Stockholm Declaration provides that "States shall take all possible steps to prevent pollution of the seas by substances that are liable to create hazards to human health, to harm living resources and marine life, to damage amenities or to interfere with other legitimate uses of the sea”. In 1992, the Rio Declaration does not make any direct reference to oceans and seas, but Chapter I7 of Agenda 2I and developments (i) related define the relationship between sustainable development and the Law of the Sea, when Small Island Developing States (ii) appear a case study.

\section{(i) Chapter 17 of Agenda 2I and Developments}

Chapter 17 of Agenda 2I, the implementation action plan of the Rio Conference, is especially dedicated to Protection of the oceans, all kinds of seas, including enclosed and semi-enclosed seas, and coastal areas and the protection, rational use and development of their living resources. ${ }^{28}$

This chapter defines the marine environment - including the oceans and all seas and adjacent coastal areas - as an integrated whole, an essential component of the global life-support system and a positive asset presenting opportunities for sustainable development.

It recalls that International Law, as reflected in the provisions of LOSC, sets forth rights and obligations of states and provides the international basis upon which to pursue the protection and sustainable development of the marine and coastal environment and its resources.

In this perspective, Chapter 17 requires new approaches to marine and coastal area management and development, as reflected in seven programme areas encompassing a global approach of the new Law of the Sea: I - Integrated management and sustainable development of coastal areas, including exclusive economic zones; 2 - Marine environmental protection; 3 - Sustainable use and conservation of marine living resources of the high seas; 4 - Sustainable use and conservation of marine living resources under national jurisdiction; 5 - Addressing critical uncertainties for the management of the marine environment and climate change; 6 - Strengthening international, including regional,

\footnotetext{
28 Chapter I7 of Agenda 2 I.
} 
cooperation and coordination; 7 - Sustainable development of small islands. ${ }^{29}$

Most of these issues remained essential twenty years after the Earth Summit, as evidenced by the follow up developments, especially the Rio+2o Conference and its final document called The future we want, , $^{\circ}$ in its developments devoted to Oceans and seas ( $\$$ I58-I77), in close connection with LOSC but also taking into consideration new challenges, ${ }^{31}$ such as illegal fishing, preservation of the marine environment, biodiversity protection, climate change, and obviously Small Island Developing States ( $\S$ I78-180).

\section{(ii) Small Island Developing States (SIDS)}

In 1992, Chapter 17 last programme area was especially dedicated to Sustainable development of small islands.32 Small Island Developing States and islands supporting small communities are a special case both for environment and development. Chapter 17 called for developing and strengthening interisland, regional and interregional cooperation and information exchange, including periodic regional and global meetings on sustainable development of Small Island Developing States (SIDS).

This was the starting point of specific follow up actions such as the Global Conference on Sustainable Development of Small Island Developing States held in Barbados in 1994, with the adoption of the Barbados Programme of Action (BPOA), further complemented by the Mauritius Strategy of Implementation (MSI) of 2005 and MSI+5 Outcome document (20IO), the Rio+20 Conference and the SAMOA (SIDS Accelerated Modalities Of Action) Pathway adopted by the Third SIDS Conference in 20I4.33

The SAMOA Pathway reaffirms that SIDS are a special case for sustainable development and remain constrained in meeting their goals in all three dimensions of sustainable development; they are afflicted by economic difficulties and confronted by development imperatives similar to those of developing countries generally, but the difficulties they face in the pursuit of sustainable development are particularly severe and complex, because of their own peculiar vulnerabilities and characteristics: small size, limited resources, geographic dispersion and isolation from markets, but also climate change $^{34}$ and sea-level rise, including natural and environmental disasters. ${ }^{35}$ The long-term effects of climate change may even threaten the very existence and viability of some SIDS. ${ }^{36}$

\footnotetext{
29 For a critical analysis of Chapter 17 of Agenda 2I, cf. U. Beyerlin, 'New Developments in the Protection of the Marine Environment: Potential Effects of the Rio Process', Zeitschrift für ausländisches öffentliches Recht und Völkerrecbt Heidelberg Journal of International Law (1995) 544-579.

30 The future we want.

3I G.A. Oanta, 'Protection and Preservation of the Marine Environment as a Goal for Achieving Sustainable Development on the Rio+20 Agenda', International Community Law Review (2014) 214-235 [DOI: 10.I163/187719732-I234I277].

${ }_{32} \quad$ I7 G, I7.123-17.136.

33 SAMOA Pathway.

34 On this general issue, cf. A. Gillespie, 'Small Island States in the Face of Climatic Change: The End of the Line in International Environmental Responsibility', UCLA Journal of Environmental Law and Policy (2003/2004) I07-I29.

35 For a pluridisciplinary approach, VertigO - la revue électronique en sciences de l'environnement, Volume io Numéro 3, décembre 20IO, Les petits États et territoires insulaires face aux changements climatiques : vulnérabilité, adaptation et développement.

36 M.J. Aznar Gómez, 'El Estado sin territorio: la desaparición del territorio debido al cambio climático', 26 Revista
} 
This is part of the current legal approaches reflected both in the field of sustainable development and in the framework of the Law of the Sea.

\section{(2) Current Legal Approaches}

Indeed, the concept of sustainable development appears to be correlated with a new set of principles and rules (a) defining rights and obligations of states (b) in International Law, and especially in the Law of the Sea.

\section{(a) A New Set of Principles and Rules}

The new International Law framework appears to be at the crossroads, 37 between the contribution of LOSC and the new Law of the Sea (i) and the contribution of the Biological Diversity Convention and Rio outcomes (ii).

\section{(i) Contribution of LOSC and the New Law of the Sea}

Although LOSC predates the emergence of sustainable development, the Third Conference began in 1973, one year after the first environmental conference, and it may be considered an innovative experience because it is looking for a balance between economic development and environmental concern, rights of coastal states over maritime areas and resources and an anthropocentric conception of environmental protection.

As regards the rights of coastal states over maritime areas and resources, and considering the dates, LOSC appears largely influenced by the ideology of development, especially the doctrine of permanent sovereignty over natural resources, stated by UN General Assembly Resolution I803 (XVII). $3^{8}$ It is mainly pursuant to this approach and under the influence of developing states that the 1982 Convention has realized the dynamic of creeping jurisdiction initiated by the Geneva Conventions in 1958 , intensifying the territorialization of the oceans and seas, both in terms of distance and competences. ${ }^{29}$

But coastal nationalism may, and has, also to be construed as a claim for economic sovereignty, as evidenced by the chronological history of the concept of economic exclusive zone (EEZ). Indeed it originates first in the claims of South American states bordering the Pacific (Chile, Peru, and Ecuador $)^{40}$ in order to benefit the rich Humboldt Current, in 1947 and under the famous Santiago Declaration of $1952 .^{4}$ Then it was developed during the negotiation thanks to the activism of

\footnotetext{
Electrónica de Estudios Internacionales (2013).

37 Cf. R. Wolfrum \& N. Matz, 'The Interplay between the United Nations Convention on the Law of the Sea and the Convention on Biological Diversity', Max Planck Yearbook of United Nations Law (2000) 445-480.

${ }_{38}$ Resolution I803 (XVII), I4 December 1962, Permanent sovereignty over natural resources; cf. G. Fischer, 'La souveraineté sur les ressources naturelles', Annuaire français de droit international (1962) 516-528 [DOI: 10.3406/afdi.1962.985]; N. Schrijver, Sovereignty over natural resources: Balancing rights and duties (Cambridge University Press, 1997), especially Chapter 7 'The Law of the Sea: Extension of Control over Marine Resources', at 202-230.

39 Cf. G. Apollis, L'emprise maritime de l'Etat côtier (Pédone, Paris, 198I).

40 Cf. H. Llanos Mansilla, 'Los países del sistema del Pacifico Sur ante la Convención sobre derecho del mar', Revista chilena de derecho (1983) 2I-38.

${ }_{41}$ Declaración sobre Zona Marítima, Santiago, i8 de agosto de 1952.
} 
developing states, the contribution of Latin-Americans, especially with the Declaration of Santo Domingo of $1972^{42}$ which articulated the notion of patrimonial sea, and the work of the Asian-African Legal Consultative Committee, culminating with the Addis Ababa Declaration of 1973, and the final African proposition. ${ }^{43}$ Developed states were originally reluctant and even strongly opposed to the concept, adopted in Caracas in 1974, before understanding it would also be of great benefit for them and finally supporting it. ${ }^{4}$

Furthermore, such an approach is associated with an anthropocentric conception of environmental protection. Indeed, in the spirit of LOSC, this economic sovereignty, conceived as an instrument of development, is supposed to be balanced with some environmental concerns stemming from Stockholm principles, especially Principle 7 declaring that "States shall take all possible steps to prevent pollution of the seas". De facto, LOSC only deals with marine pollution; in accordance with the traditional approach ${ }^{45}$ reflected in the agenda of the Third Commission of the Conference, Part $\mathrm{XII}$ is devoted to Protection and preservation of the marine environment. ${ }^{46}$ Its first disposition, Article 192 transposes into the Law of the Sea the General obligation, already well-known in the Law of the Environment, stating that "States have the obligation to protect and preserve the marine environment". According to Principle 2I of Stockholm, ${ }^{47}$ "States have the sovereign right to exploit their natural resources pursuant to their environmental policies and in accordance with their duty to protect and preserve the marine environment", as provided for in Article 193 on the Sovereign right of States to exploit their natural resources.

Within the context of the Convention, all environmental concerns must be understood, in reference to a utilitarian kind of logic, finalized and functional, and essentially in connection with economic usages of the sea. The need to fight against pollution gives rise to an anthropocentric approach, primarily focused on the impact of human activities, and first of all related to the prevention of, preparedness for and response to marine pollution. Basically, Part XII is aimed at

42 Declaración de Santo Domingo aprobada por la Reunión de Ministros de la Conferencia Especializada de los Países del Caribe sobre los Problemas del Mar (1972).

43 A. Del Vecchio, Zona economica esclusiva e Stati costieri (Le Monnier - Libera Università Internazionale degli Studi Sociali, Roma, 1984), at 6I-II3; F. Orrego Vicuña, 'La zone économique exclusive : régime et nature juridique dans le droit international', 199 Recueil des cours de l'Académie de droit international de La Haye (1986), at 20-26.

44 See, for example, in France the adoption of the loi $n^{\circ} 76-655$ du 16 juillet 1976 relative à la zone économique et à la zone de protection écologique au large des côtes du territoire de la République. Cf. R. Ladreit de Lacharrière, 'La zone économique française de 200 milles', Annuaire français de droit international (1976) 641-652 [DOI: 10.3406/afdi.1976.2006].

45 L.A. Teclaff, 'International Law and the Protection of the Oceans from Pollution', Fordbam Law Review (1972) 529564.

46 Articles 192 to 237. Cf. A.E. Boyle, 'Marine Pollution under the Law of the Sea Convention', American Journal of International Law (1985) 347-372; P-M. Dupuy \& M. Rémond-Gouilloud, 'La préservation du milieu marin', in R-J. Dupuy \& D. Vignes (Dir.), Traité du Nouveau Droit de la Mer (Economica Bruylant, Paris Bruxelles, 1985) 979-I045; A.Ch. Kiss, 'La pollution du milieu marin', Zeitschrift für ausländisches öffentliches Recht und Völkerrecht - Heidelberg Journal of International Law (1978) 902-932; M.L. McConnell \& E. Gold, 'The Modern Law of the Sea: Framework for the Protection and Preservation of the Marine Environment', Case Western Reserve Journal of International Law (1991) 83-I05.

47 "States have, in accordance with the Charter of the United Nations and the principles of international law, the sovereign right to exploit their own resources pursuant to their own environmental policies, and the responsibility to ensure that activities within their jurisdiction or control do not cause damage to the environment of other States or of areas beyond the limits of national jurisdiction". 
fighting the six highest forms of pollution identified at the time of the negotiations ${ }^{48}$ and likely to affect the marine environment:49 Pollution from land-based sources (Article 207); Pollution from seabed activities subject to national jurisdiction (Article 208); Pollution from activities in the Area (Article 209); Pollution by dumping (Article 210); Pollution from vessels (Article 2II); Pollution from or through the atmosphere (Article 212). States shall adopt laws and regulations to prevent, reduce and control all forms of pollution, and contain and limit as much as possible the potentially harmful effects of corresponding economic activities.

But, the contribution of the Convention on Biological Diversity and Rio outcomes have considerably enlarged the scope of environmental protection of oceans and seas, as defined by the 1982 Convention.

\section{(ii) Contribution of the Convention on Biological Diversity and Rio Outcomes}

Indeed, the $\mathrm{CBD}$ has contributed to the legal consecration of the concept of biodiversity and the development of new principles in the global context of the Rio Conference and Declaration.

Obviously LOSC neither expressly mentions nor recognizes biodiversity as such, and it would have been hard for it to be otherwise, because biodiversity, as a concept, appeared later than the adoption of the Convention. Indeed, although the term "biological diversity" was used first in $1968^{50}$

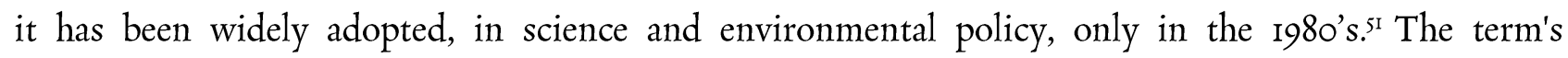
contracted form "biodiversity" seems to have been coined in 1985,52 more communicative, it began to be employed in 1986 and appeared first in a publication in 1988.53 There was no consecration of biodiversity, in International Law, till the adoption of the Convention on Biological Diversity in 1992, during the Rio Conference. The first legal reference in conventional Law of the Sea came later, with

$4^{8}$ Since then, new manifestations of pollution have been clearly identified such as acoustic pollution; cf. H.M. Dotinga \& A.G. Oude Elferink, 'Acoustic Pollution in the Oceans: The Search for Legal Standards', Ocean Development \& International Law (2000) I5I-I82; I. Papanicolopulu, 'Acoustic Pollution of the Oceans', in G. Andreone, A. Caligiuri, G. Cataldi (Dir.), Droit de la mer et émergences environnementales / Law of the Sea and Environmental Emergencies, Cahiers de l'Association internationale du Droit de la Mer I (Editoriale Scientifica, Napoli, 2012) I59-190.

49 On the most important forms of marine pollution addressed by UNCLOS, cf. D. Bodansky, 'Protecting the Marine Environment from Vessel-Source Pollution: UNCLOS III and Beyond', Ecology Law Quarterly (199I) 719-777; A. Griffin, 'MARPOL 73/78 and Vessel Pollution: A Glass Half Full or Half Empty?', Indiana Journal of Global Legal Studies (1994) 489-513; V. Labrot, 'Pollutions marines : introduction au droit international des pollutions par les navires', in A. Monaco \& P. Prouzet (Dir.), Gouvernance des mers et des océans, Collection Mer et Océan Volume 6 (ISTE Editions, London, 20I5) Chapitre 3, 87-II4; N. Ros, 'La pollution résultant de l'exploitation du sol et du sous-sol : le cas du plateau continental', in Droit des sites et sols pollués. Bilans et perspectives (L'Harmattan, Paris, 20I7) forthcoming; L. Taschereau, 'La nouvelle convention sur le droit de la mer et la lutte contre la pollution marine d'origine tellurique', Les Cabiers de droit (1983) 323-377 [DOI: I0.7202/042550ar]; Y. Tanaka, 'Regulation of Land-Based Marine Pollution in International Law: A Comparative Analysis Between Global and Regional Legal Frameworks', Zeitscbrift für ausländisches öffentliches Recht und Völkerrecbt Heidelberg Journal of International Law (2006) 535-574; T. Treves, 'La pollution résultant de l'exploration et de l'exploitation des fonds marins en droit international', Annuaire français de droit international (1978) 827-850 [DOI: 10.3406/afdi.1978.2128].

so R.F. Dasmann, A Different Kind of Country (Collier Books, 1968).

sI It is supposed to have been officially used first by the biologist Thomas Lovejoy in his preface of the book M.E. Soulé, Conservation biology: an evolutionary-ecological perspective (Sinauer Associates, 1980).

${ }_{52}$ It was invented by W.G. Rosen, during the preparation of the National Forum on Biological Diversity organized in 1986 by the National Research Council, an American NGO.

${ }_{53}$ The term was widely used during the aforementioned forum, convened in 1986, and it was chosen to be the title of the publication of its proceedings by American sociobiologist Edward Osborne Wilson; cf. E.O. Wilson, Biodiversity (National Academies Press, 1988). 
the Agreement for the Implementation of the Montego Bay Convention of 1995, relating to straddling and highly migratory fish stocks; its Article 5 paragraph $g$ was the first disposition to state an obligation to "protect biodiversity in the marine environment". 54

Etymologically, "biodiversity" is a neologism based on the Greek "bios", meaning "life", and "diversity" designating the variety and diversity of the living world; it can be defined as the natural diversity of living organisms as it develops in space and time, and consequently that of ecosystems, species and genes. In legal terms, the Rio Conference has not only defined the concept as such under Article 2 of the CBD,5 but it has also imposed biological diversity as a component of sustainable development, through the adoption of the whole Convention. Indeed, the 1992 Convention has stated the importance of biological diversity and the need to conserve it and use it sustainably. ${ }^{56}$ Its Preamble has not only reaffirmed "that States have sovereign rights over their own biological resources", but also that they "are responsible for conserving their biological diversity and for using their biological resources in a sustainable manner". As stated by Principles 2I of Stockholm and 2 of Rio, and recalled by Article 3, "States have [...] the sovereign right to exploit their own resources pursuant to their own environmental policies". In the specific case of marine biodiversity, the meaning and scope of the equation "sovereign rights over resources/obligations to conserve biological diversity" are confirmed under Article 22 Relationship with Other International Conventions, which paragraph 2 states: "Contracting Parties shall implement this Convention with respect to the marine environment consistently with the rights and obligations of States under the law of the sea". ${ }^{7}$

Development of new principles complements this contribution as regards sustainable development. One of the most important of these principles is the principle of common but differentiated responsibilities which stems both from Rio Declaration and the CBD. According to Principle 7 of the Rio Declaration, and "in view of the different contributions to global environmental degradation, States have common but differentiated responsibilities"; and pursuant to Principle 6, "the special situation and needs of developing countries, particularly the least developed and those most environmentally vulnerable, shall be given special priority". Implementing these provisions, the CBD establishes a differentiated approach in favor of developing countries, least advanced countries and small island states, including access to and transfer of technology, technical and scientific cooperation, financial resources and mechanism. One of its objectives is the fair and equitable sharing of the benefits arising out of the utilization of genetic resources, ${ }^{58}$ which has been confirmed by the Nagoya

\footnotetext{
54 J-P. Beurier, 'La protection juridique de la biodiversité marine', in Pour un droit commun de l'environnement: mélanges en l'bonneur de Michel Prieur (Dalloz, Paris, 2007) 803-815.

55 "Biological diversity' means the variability among living organisms from all sources including, inter alia, terrestrial, marine and other aquatic ecosystems and the ecological complexes of which they are part: this includes diversity within species, between species and of ecosystems".

56 The conception adopted in 1992 was largely influenced by developing states, against the conservationist approach supported by developed states; cf. M-A. Hermitte, 'La convention sur la diversité biologique', Annuaire français de droit international (1992) 844-870 [DOI : I0.3406/afdi.1992.3098]. For a legal analysis, cf. J-P. Beurier, 'Le droit de la biodiversite', Revue Juridique de l'Environnement (1996) 5-28 [DOI: I0.3406/rjenv.1996.3255].

57 Cf. R. Wolfrum \& N. Matz, 'The Interplay between the United Nations Convention on the Law of the Sea and the Convention on Biological Diversity', Max Planck Yearbook of United Nations Law (2000) 445-480.

58 The Convention's three objectives are the conservation of biological diversity, the sustainable use of its components
} 
Protocol adopted on 29 October 2010 and entered into force on 12 October 2010.59

According to an approach that is now widely adopted by most of the legal systems, Article I4 states the principle of "environmental impact assessment" also included in the Rio Declaration (Principle I7). But, for the future of Environmental Law, the most important principle emerging during the Rio Conference is the "precautionary approach", only mentioned in the soft law Declaration of Rio (Principle 15). Other new soft law principles are also considered as Rio outcomes, although they are not all expressly mentioned in the Rio Declaration or Agenda 2r: such as, for example, "polluter pays principle", "integrated management of the coastal zones", "best available techniques" and "best environmental practices". Rights and obligations of states must be understood in this global hard and soft law framework.

\section{(b) Rights and Obligations of States}

Indeed, in contemporary International Law, and in a perspective of sustainable development, sovereign rights of coastal states (i) and correlative obligations of coastal states (ii) are to be defined in this new double legal context.

\section{(i) Sovereign Rights of Coastal States}

Coastal states have economic rights, both on the resources of the superjacent waters and on the continental shelf and its resources.

As regards the resources of the superjacent waters, and in addition to the sovereignty the state exercises over its territorial sea, it has sovereign rights and jurisdiction in the exclusive economic zone. $^{60}$ The rights are economic and exclusive, but extend over natural resources, not over the zone itself. As stated under Article $56 \oint$ I a, "the coastal State has sovereign rights for the purpose of exploring and exploiting, conserving and managing the natural resources, whether living or non-living, of the waters superjacent [...], and with regard to other activities for the economic exploitation and exploration of the zone, such as the production of energy from the water, currents and winds"; both fishing activities and marine renewable energies are at stake, and can be considered sustainable development challenges.

It is well known that the most important part of these economic rights is traditionally devoted to fishing activities; this is perfectly explained by the history of the EEZ concept. Although the special situation of developing (Article $62 \$ 2 \& 3$ ), landlocked (Article 69) or geographically disadvantaged states (Article 70), is supposed to be taken into consideration, according to sustainable development

and the fair and equitable sharing of benefits arising from the utilization of genetic resources.

59 On related issues, cf. T. Burelli, 'Faut-il se réjouir de la conclusion du Protocole de Nagoya ?', Revue Juridique de l'Environnement (2012) 45-6r; E. Chege Kamau, B. Fedder, G. Winter, 'The Nagoya Protocol on Access to Genetic Resources and Benefit Sharing: What is New and What are the Implications for Provider and User Countries and the Scientific Community?, Law, Environment and Development Journal (2010) 246-262; R. Zahluth Bastos et al., 'Le régime international de l'accès aux ressources génétiques au prisme de l'entrée en vigueur du Protocole de Nagoya', Revista de Direito Internacional - Brazilian Journal of International Law (2016) I30-146 [DOI: 10.5102/rdi.vi3i2.4069].

${ }^{60}$ F. Orrego Vicuña, 'La zone économique exclusive : régime et nature juridique dans le droit international', in 199 Recueil des cours de l'Académie de droit international de La Haye (1986) 9-170. 
principles, the Convention creates a monopolistic situation for the coastal state, both as regards the conservation (Article 6I) and the exploitation (Article 62) of living resources. Neither the temporal dimension of sustainable development nor the spatial one are properly implemented; as regards conservation of biological resources, states are more eager to ensure the profitability of the exploitation, with the "objective of optimum utilization" (Article $62 \S \mathrm{I}$ ), according to the logic of LOSC, than to preserve biodiversity.

The sovereign rights the coastal state enjoys in the EEZ are complemented by a triple jurisdiction, with regard to "the establishment and use of artificial islands, installations and structures; marine scientific research; and the protection and preservation of the marine environment". Under Article 60, the coastal states have exclusive rights and jurisdiction over artificial islands, installations and structures located in the exclusive economic zone and used for economic purposes; of course, offshore wind and hydro-electric farms are considered sustainable development challenges, but more traditional offshore industries are also concerned. ${ }^{6}$ Nevertheless, and notwithstanding such an ambiguity, Article $56 \$ 3$ provides that "the rights set out $[\ldots]$ with respect to the seabed and subsoil shall be exercised in accordance with Part VI", that is to say with regard to the continental shelf.

As stated by Article 77 of LOSC, "the coastal State exercises over the continental shelf sovereign rights for the purpose of exploring it and exploiting its natural resources" ( $\left.\S_{\mathrm{I}}\right)$; these "rights [...] are exclusive in the sense that if the coastal State does not explore the continental shelf or exploit its natural resources, no one may undertake these activities without [its] express consent" $(\$ 2)$; furthermore, "the rights of the coastal state over the continental shelf do not depend on occupation, effective or notional, or on any express proclamation" $\left(\S_{3}\right)$.

In other words, there exists a state monopoly and the coastal state is exclusively competent to define the legal regime of exploitation of the resources on the continental shelf. ${ }^{62}$ It is the one and only authority competent to explore (including the preliminary phase of prospection), exploit or authorize offshore activities. It delivers licenses, permits and any kind of authorizations, according to its domestic legislation. ${ }^{6}$ Furthermore, "the coastal State shall have the exclusive right to authorize and regulate drilling on the continental shelf for all purposes" (Article 8I) and also the exclusive right to construct and to authorize and regulate the construction, operation and use of artificial islands, installations and structures on the continental shelf, with exclusive jurisdiction over them (Article $80){ }^{64}$

6r As evidenced in the Mediterranean, taking into consideration recent EEZ proclamations; cf. N. Ros, 'Les nouvelles zones économiques exclusives en mer Méditerranée', in N. Ros \& F. Galletti (Dir.), Le droit de la mer face aux "Méditerranées", Quelle contribution de la Méditerranée et des mers semi-fermées au droit international de la mer ?, Cahiers de l'Association internationale du Droit de la Mer 5 (Editoriale Scientifica, Napoli, 2016) 7-33.

62 V. Marotta Rangel, 'Le plateau continental dans la Convention de 1982 sur le droit de la mer', I94 Recueil des cours de l'Académie de droit international de La Haye (1985) 269-428.

63 Therefore, legal differences are very important from one state to another. For a very interesting study of comparative legislation, conducted in France by the Division de Législation comparée de la Direction de l'Initiative parlementaire et des délégations, at the request of the Délégation sénatoriale de l'Outre-Mer, cf. Note sur L'exploration et l'exploitation pétrolières en mer (Australie - Brésil - Mexique - Norvège - Royaume-Uni), République française, janvier 2013.

${ }_{4}$ Cf. G. Andreone, 'The Powers of Coastal States over Offshore Oil Platforms', in A. Caligiuri (Ed.), Governance of the Adriatic and Ionian Marine Space, Final publication MaReMaP-AIR, Cahiers de l'Association internationale du Droit de la 
The coastal state's rights are not only sovereign and exclusive, but also economic and finalized, in that they are oriented towards the exploration and exploitation of the "natural resources" of the continental shelf, which "consist of the mineral and other non-living resources of the seabed and subsoil together with living organisms belonging to sedentary species" (Article $77 £ 4$ ). Obviously, the most important part of the natural resources of the continental shelf are mineral resources and especially hydrocarbons, oil and gas; but seabed mining for other minerals may also be involved, as well as exploitation of underwater sand deposits to replenish beaches. As far as living resources are concerned, only sedentary species are expressly mentioned, ${ }^{65}$ which traditionally refers to some crustaceans but now includes deep-water corals and other sedentary species inhabiting seamounts and hydrothermal vents likely to be considered as marine genetic resources; although prospectively, these living resources represent a significant issue, particularly in the context of current negotiations at the United Nations. For developing and developed states, all the resources of the continental shelf are promises of economic development; in this perspective, sustainable development objectives can hardly be considered priorities, such as correlative obligations of coastal states.

\section{(ii) Correlative Obligations of Coastal States}

Pursuant to LOSC and International Law, most of these obligations are conceived especially for environmental protection, but it seems actually impossible to strike a balance between exploitation and protection, a fortiori taking into consideration the economic context, in particular the current systemic crisis.

LOSC, especially its Part XII, imposes a legal objective of conservation and preservation of the marine environment. According to Article 194 Measures to prevent, reduce and control pollution of the marine environment, and in a general way, "States shall take [...] all measures [...] that are necessary to prevent, reduce and control pollution of the marine environment from any source". As regards the EEZ, Article $56 \$ \mathrm{I}$ b provides coastal state jurisdiction with regard to "the protection and preservation of the marine environment", especially to fight against pollution from land-based sources, dumping and vessels. With respect to fishing activities, and in order to support their economic profitability, Article 6I $\$ 2$ disposes that coastal state "shall ensure through proper conservation and management measures that the maintenance of the living resources in the exclusive economic zone is not endangered by over-exploitation”. On the continental shelf, coastal states are under a special obligation to prevent, reduce and control Pollution from seabed activities subjects to national jurisdiction, as provided for under Article 208, including "pollution of the marine environment arising from or in connection with seabed activities subject to their jurisdiction and from artificial islands, installations and structures under their jurisdiction, pursuant to articles 60 and 80 " $(\$ \mathrm{I})$. Considered to be one of the most important and most dangerous forms of marine pollution, offshore is thus directly addressed by LOSC and the new Law of the Sea, and the coastal state is vested with all the

Mer 4 (Editoriale Scientifica, Napoli, 2016) 191-202.

${ }_{65}$ Article $77 \S 4$ refers to "sedentary species, that is to say, organisms which, at the harvestable stage, either are immobile on or under the seabed or are unable to move except in constant physical contact with the seabed or the subsoil". 
general competences in order to fight against its dangers. ${ }^{66}$

In reality, the problem is twofold: despite sustainable development objectives, environmental concerns cannot be a priority, especially for developing states; furthermore, states, even developed countries, are more and more confronted to a lack of means, together human, logistic, financial and material, in order to effectively address pollution and non-sustainable exploitation practices. Despite the general rule stating that the right to exploit resources, living or non-living, shall not prevent states from protecting the marine environment and its biodiversity, the consequence is an impossible balance between exploitation and protection; on the contrary, both aspects have to be balanced in accordance with sustainable development, at the crossroads of LOSC and CBD requirements. The difficulties resulting from underdevelopment largely explain that economic promises of the exploitation of natural resources prevent these states from adopting a balanced approach, integrating environmental concerns, in accordance with sustainable development logic. The needs of present and future generations appear impossible to conciliate. But the most deceiving point is that most of the time, the exploitation of non-renewable resources does not even serve economic development purposes and does not benefit the people but a minority, connected with industrial lobbies, especially in the case of offshore activities, ${ }^{67}$ or even to mafias as regards illegal fishing. ${ }^{68}$ The most significant, but also the most disheartening, in a sustainable development perspective, is that these situations also exist in developed countries, where old democratic systems and their political leaders prove to be unable to strike a balance between the short term prospects of economic exploitation and the long term objectives of environmental protection, a fortiori in the current context of crisis.

These are the current challenges of economic exploitation of sea resources, given that a sustainable development approach should always imply that wisdom prevails over greed...

\section{(B) CHALLENGES OF ECONOMIC EXPLOITATION}

Indeed, receptive to environmental concerns and obviously geopolitical, the new Law of the Sea is also characterized by its economic dimension; thus, a great number of sustainable development objectives appear to be at stake, both in the surperjacent waters (I) and on the seabed and subsoil (2).

66 Cf. J.W. Kindt, 'The Law of the Sea: Offshore Installations and Marine Pollution', Pepperdine Law Review (1985) 381426; N. Ros, 'La pollution résultant de l'exploitation du sol et du sous-sol : le cas du plateau continental', in Droit des sites et sols pollués. Bilans et perspectives (L'Harmattan, Paris, 2017) forthcoming; and for a regional approach, 'Exploration, Exploitation and Protection of the Mediterranean Continental Shelf, in C. Cinelli \& E.M. Vásquez Gómez (Ed.), Regional Strategies to Maritime Security: a Comparative Perspective, MARSAFENET (Tirant lo Blanch, Valencia, 2OI4) IOI-I32.

${ }_{67}$ This was evidenced by the Petrobras scandal in Brazil and in fine by the French Code minier since an amendment to the 1994 Finances Law, adopted in 1993, and never challenged since then; indeed in accordance with this provision, offshore exploitation on the French continental shelf is free from all financial and fiscal rights, taxes and other royalties... Cf. N. Ros, 'Au-delà de la borne 602 : la frontière maritime entre l'Espagne et la France en mer Méditerranée', 4 Journal du Droit international Clunet (20I4), at IIO7-IIIO; 'La pollution résultant de l'exploitation du sol et du sous-sol: le cas du plateau continental', in Droit des sites et sols pollués. Bilans et perspectives (L'Harmattan, Paris, 20I7) forthcoming.

68 J.M. Sobrino Heredia, 'Una nueva manifestación de delincuencia organizada internacional: las actividades de pesca ilegal, no declarada y no reglamentada', in J. Juste Ruiz \& V. Bou Franch (Dir.), Derecho del mar y sostenibilidad ambiental en el Mediterráneo (Tirant lo Blanch, Valencia, 20I3) I47-I74. 
(I) In the Surperjacent Waters

Fishing activities (a) are still an essential issue in terms of sustainable development, but biodiversity on the bigh seas (b) is the most current preoccupation.

\section{(a) Fishing Activities}

Since the late $20^{\text {th }}$ century, imperatives of sustainable management of fisheries (i) have imposed the necessity of fighting against illegal fishing (ii).

\section{(i) Sustainable Management of Fisheries}

Fishing activities are a potential for sustainable development, but the traditional regime of freedom, based on the alleged myth of inexhaustibility of living resources, erroneously attributed to Grotius, ${ }^{69}$ led to overexploitation with the introduction of industrial methods. Coastal states reactions led to the creation of the EEZ, and the adoption of dedicated International Law including for high seas fisheries, ${ }^{70}$ both normative under LOSC and the 1995 Agreement, ${ }^{71}$ and institutional with the development of Regional Fisheries Management Organizations (RFMOs); $;^{72}$ but this evolution was unable to introduce a sustainable approach because of short term economic priorities.73

In terms of sustainable development, great problems remain for the future: overexploitation,

69 In fact, Grotius can be considered to have sensed the exhaustible character of biological resources: piscaturam qua dici quodammodo potest pisces exbauriri, in other words "fisheries, about which it can in some way be maintained that fish stocks are exhaustible" (translation in modern English is by the author); H. Grotius, Mare Liberum The freedom of the seas, I608, the quotation is at the end of Chapter V, Carnegie Endowment for International Peace (Oxford University Press, New York, I9I6), at 43 .

$7^{\circ}$ Cf. M. Le Hardy, Que reste-t-il de la liberté de la pêche en baute mer? De l'exploitation individuelle à la gestion collective. Essai sur le régime juridique de l'exploitation des ressources biologiques de la baute mer (Pédone, Paris, 2002); F. Orrego Vicuña, The Changing International Law of High Seas Fisheries (Cambridge University Press, 2003); E.M. Vázquez Gómez, 'La obligación de cooperar para conservar los recursos pesqueros del alta mar frente a la creeping jurisdiction institucionalizada', in J.M. Sobrino Heredia (Dir.), La contribution de la Convention des Nations Unies sur le droit de la mer à la bonne gouvernance des mers et des océans / La contribución de la Convención de las Naciones Unidas sobre el Derecho del Mar a la buena gobernanza de los mares y océanos / The Contribution of the United Nations Convention on the Law of the Sea to Good Governance of the Oceans and Seas, Cahiers de l'Association internationale du Droit de la Mer 2 (Editoriale Scientifica, Napoli, 2014) Volume I, 429-438.

${ }^{71}$ W.T. Burke, Fisheries regulations under extended jurisdiction and international law, FAO Fish.Tech.Pap. 223 (FAO, Rome, 1982); C.A. Fleischer, 'La pêche', in R-J. Dupuy \& D. Vignes (Dir.), Traité du Nouveau Droit de la Mer (Economica Bruylant, Paris Bruxelles, 1985) 819-956; D. Momtaz, 'L'accord relatif à la conservation et à la gestion des stocks de poissons chevauchants et de grands migrateurs', Annuaire français de droit international (1995) 676-699 [DOI: 10.3406/afdi.1995.3350]; J.A. de Yturriaga Barberán, 'Perspectives on High Seas Fisheries after UNCLOS', in J.M. de Faramiñán Gilbert \& V.L. Gutiérrez Castillo (Dir.), Coopération, sécurité et développement durable dans les mers et les océans. Une référence spéciale à la Méditerranée / Sea and ocean-related cooperation, security and sustainable development. An analysis with a special focus on the Mediterranean (Huygens Editorial Lex Científica, Barcelona, 2013) Chapter II, 230-257.

72 J. Beer-Gabel \& V. Lestang, Les Commissions de pêche et leur droit. La conservation et la gestion des ressources marines vivantes (Bruylant, Bruxelles, 2003); E.M. Vázquez Gómez, Las Organizaciones Internacionales de Ordenación Pesquera. La Cooperación para la Conservación y la Gestión de los Recursos Vivos del Alta Mar, Sociología y Política Pesquera (Junta de Andalucía Consejería de Agricultura y Pesca, 2002).

73 Cf. W. Edeson, 'Sustainable Use of Marine Living Resources', Zeitschrift für ausländisches öffentliches Recht und Völkerrecht - Heidelberg Journal of International Law (2003) 355-376; O. Spijkers \& N. Jevglevskaja, 'Sustainable Development and High Seas Fisheries', Utrecht Law Review (2013) 24-37; G. Winter (Ed.), Towards Sustainable Fisheries Law. A Comparative Analysis, IUCN Environmental Policy and Law Paper $N^{\circ} 74$ (IUCN, Gland, 2009). 
depletion of some stocks and announced disappearance of certain species, unsustainable fishing practices, such as bottom fishing, or bycatches and discards equivalent to more than one quarter of global captures. ${ }^{74} \mathrm{~A}$ large part of fishing activities is unsustainable, but they have also failed to become a mean of economic development for developing countries. In theory, special needs of developing states are always supposed to be taken into consideration and a differentiated approach is recommended but, in practice, these countries still lack financial, human and logistic means. Furthermore, the crisis of fisheries, both industrial and artisanal in developed states, has also indirectly affected their situation, in particular because it has transferred fishing efforts and some unsustainable practices, schematically from North to South. The necessity to reduce overcapacity in fishing fleets, especially thanks to the prohibition of fisheries subsidies, as in the World Trade Organization, is also a good example, because developing states logically claim for a special and differential treatment; ${ }^{75}$ but developing states can also serve as flags of convenience, without effective incomes likely to better economic development.

The development of International Law of fisheries, the progressive extension of sovereign rights and interests of coastal states, and the conditioning of freedom even on the high seas, in particular with the development of Regional Fisheries Management Organizations (RFMOs), led to illegal fishing practices ${ }^{76}$ and invested the international community with the obligation of fighting against illegal fishing.

\section{(ii) Fighting against Illegal Fishing}

IUU fishing, illegal, unreported and unregulated, is a real scourge in terms of sustainable development. It is not only one of the most serious threats to sustainable exploitation of living resources, but also to marine biodiversity preservation; it also undermines social standards and distorts markets. From all these points of view, it is an obstacle to the three dimensions of sustainable development.

The first reason why IUU fishing is a particularly critical issue today is that many fish stocks are already overexploited by legal fishing activities; therefore, illegal practices put fish stocks under additional pressure, exacerbating overfishing problems and consequences. As regards the environmental dimension of sustainable development, IUU fishing mortgages the future, both in terms of volume of captures and depletion of stocks and species.

\footnotetext{
74 The State of World Fisheries and Aquaculture. Contributing to food security and nutrition for all (FAO, Rome, 2016).

75 Cf. C. Teijo García, 'El desarrollo progresivo de las normas sobre subvenciones pesqueras en el Derecho de la OMC: una aproximación a la conservación de los recursos pesqueros desde la perspectiva del Derecho internacional del comercio', in J. Jorge Urbina \& M.T. Ponte Iglesias (Coord.), Protección de intereses colectivos en el Derecho del Mar y cooperación internacional (Iustel, Madrid, 20I2) I09-I40.

${ }^{6}$ J.M. Sobrino Heredia, 'La tensión entre la gobernanza zonal y la gobernanza global en la conservación y gestión de los recursos pesqueros', in J.M. Sobrino Heredia (Dir.), La contribution de la Convention des Nations Unies sur le droit de la mer à la bonne gouvernance des mers et des océans / La contribución de la Convención de las Naciones Unidas sobre el Derecho del Mar a la buena gobernanza de los mares y océanos / The contribution of the United Nations Convention on the Law of the Sea to good governance of seas and oceans, Cahiers de l'Association internationale du Droit de la Mer 2 (Editoriale Scientifica, Napoli, 20I4) Volume II, 455-483.
} 
IUU fishing is a worldwide phenomenon, taking place on a large scale in the territorial waters or exclusive economic zones, and on the high seas.77 Obviously, its development is easier in countries which cannot afford to set up costly and complex fisheries control structures, such as developing countries. In these states, illegal fishing hampers economic development and fosters the looting of natural resources, depriving fishermen from jobs and incomes, what can also be an incentive to piracy... and anyway prevents alleviation of poverty.

This is part of the social impact of IUU fishing, which contributes to the fisheries crisis worldwide, in developed and developing states. Indeed, due to its transnational criminal organization, ${ }^{78}$ illegal fishing is also a social and human scourge. Vessels illegally fishing are very often flying flags of convenience; 79 working conditions on board are usually very bad, both from the standpoint of safety of fishermen and human rights. ${ }^{80}$ In these conditions, fishermen from developing countries can be the designated victims of these kinds of human exploitation, from forced labor to trafficking and other slavery situations.

Fighting against IUU fishing is a prerequisite for sustainable fisheries development, a necessity but also a very complicated task. In this perspective, states, whether flag, coastal, port or market states, should cooperate and work together, in application and implementation of International Law. ${ }^{8 \mathrm{r}}$ The Agreement on Port State Measures to Prevent, Deter and Eliminate Illegal, Unreported and Unregulated Fishing, adopted by the FAO on 22 November 2009 and entered into force on 5 June 20I6, is the cornerstone of the current international legal system. ${ }^{82}$ But developing states need help in order to be able to fulfill their legal obligations, especially to control fisheries in their EEZ, and not to

77 R. Baird, 'Illegal, Unreported and Unregulated Fishing: an Analysis of the Legal, Economic and Historical Factors Relevant to its Development and Persistence', Melbourne Journal of International Law (2004) 299-334.

78 G.A. Oanta, 'Illegal Fishing as a Criminal Act at Sea', in E.D. Papastavridis \& K.N. Trapp (Eds.), La criminalité en mer / Crimes at Sea (Brill Nijhoff, Leiden Boston, 20I4) I49-I97; N. Ros, 'Halte au piratage halieutique !', Annuaire du Droit de la Mer (2002) 347-376; J.M. Sobrino Heredia, 'Una nueva manifestación de delincuencia organizada internacional: las actividades de pesca ilegal, no declarada y no reglamentada', in J. Juste Ruiz \& V. Bou Franch (Dir.), Derecho del mar $y$ sostenibilidad ambiental en el Mediterráneo (Tirant lo Blanch, Valencia, 20I3) I47-I74.

79 J.M. Sobrino Heredia, 'Pabellones de conveniencia y pesca ilegal', in M. Vargas Gómez-Urrutia \& A. Salinas de Frías (Coord.), Soberanía del Estado y derecho internacional: bomenaje al profesor Juan Antonio Carrillo Salcedo (Universidad de Sevilla, 2005) Vol. 2, I33I-I348; D. Warner-Kramer, 'Control Begins at Home: Tackling Flags of Convenience and IUU Fishing', Golden Gate University Law Review (2004) 497-529.

${ }^{80}$ Cases of abuse, forced labor and modern slavery are obviously difficult to identify and prove on vessels engaged in IUU fishing, but actually they are of course all the more numerous and serious. Cf. N. Ros, 'Cuestiones actuales de Derecho del Mar', in J. Cabeza Pereiro \& E. Rodríguez Rodríguez (Coord.), El trabajo en el Mar: los nuevos escenarios jurídicomaritimos (Editorial Bomarzo, Albacete, 2015), at 6I; R. Surtees, 'Trapped at Sea. Using the Legal and Regulatory Framework to Prevent and Combat the Trafficking of Seafarers and Fishers', Groningen Journal of International Law (2013), at $95-96$.

8I M. Morin, 'La lutte contre la pêche illicite et la responsabilité des Etats', in P. Chaumette (Dir.), Maritime areas: control and prevention of illegal traffics at sea / Espaces marins : surveillance et prévention des trafics illicites en mer (Gomylex Editorial, Bilbao, 2016) Chapter 2, 83-97; G.A. Oanta, 'New Steps in the Control of Illegal, Unreported and Unregulated Fishing', in H-J. Koch et al. (Eds.), Legal Regimes for Environmental Protection: Governance for Climate Change and Ocean Resources (Brill Nijhoff, Leiden Boston, 2015) 229-257; N. Ros, 'La lutte contre la pêche illicite', in G. Andreone, A. Caligiuri, G. Cataldi (Ed.), Droit de la mer et émergences environnementales / Law of the Sea and Environmental Emergencies, Cahiers de l'Association internationale du Droit de la Mer I (Editoriale Scientifica, Napoli, 2012) 69-I22.

82 Cf. the trilingual revised edition of the 2009 Agreement; for a commentary, M. Morin, 'L'accord FAO sur les mesures de contrôle des navires par l'Etat du port', Annuaire de Droit Maritime et Océanique (2010) 393-4Io. 
be condemned to become flags or ports of convenience.

Obviously the high seas are also concerned by illegal fishing, but beyond national jurisdiction the most important challenge is now related to biodiversity on the bigh seas.

\section{(b) Biodiversity on the High Seas}

Immediately after the adoption of LOSC, problems remained concerning high seas fisheries, which led to the adoption of the 1995 Agreement on straddling and highly migratory fish stocks, ${ }^{{ }^{3}}$ and the creation of RFMOs worldwide; some fisheries related issues are still at stake, ${ }^{84}$ but the current problematic (i) is totally different as evidenced by the challenges of negotiation (ii).

\section{(i) Current Problematic}

Taking note of the threats and risks to vulnerable and threatened marine ecosystems and biodiversity in areas beyond national jurisdiction, especially seamounts, cold water corals, hydrothermal vents and other underwater features, ${ }^{85}$ General Assembly Resolution A/RES/59/24, adopted on 17 November 2004, has established an ad hoc open-ended informal working group to study issues relating to the conservation and sustainable use of biodiversity beyond national jurisdiction (BBNJ). ${ }^{86}$

According to initial concerns, the first meeting of the working group, convened in 2006, focused its exchanges on IUU fishing and destructive fishing practices, marine genetic resources (MGRs), marine scientific research (MSR), and high seas marine protected areas (MPAs). But two years later, the second session gave up discussions on high seas fisheries and centered the debates on MPAs, MGRs, MSR and technology transfer, and environmental impact assessments (EIAs). In fact, it was only in 20Ir, during the fourth meeting, that the option of a multilateral agreement under LOSC was first mentioned, in connection with a consensus on a "package deal", or at least a "package", corresponding to the set of issues defined in 2008.

In 20I2, the Rio+2o Conference adopted a document called The future we want, which paragraph I62 expressed a commitment to take a decision on the development of an international instrument under LOSC, before the end of the sixty-ninth session of the General Assembly, in 2015. In 2013 and 20I4, three meetings were engaged in a more detailed substantive discussion on the scope, parameters and feasibility of an international instrument under LOSC and based on the thematic package defined in 2008.

Finally, the ninth meeting convened in January 2015 and reached consensus on a negotiating process, by establishing a preparatory committee to make substantive recommendations on elements of a draft text of a legally binding instrument to the General Assembly in 20I7, and for the Assembly to decide at its seventy-second session, in 20I8, whether to convene an intergovernmental conference to elaborate the text of the agreement. The recommendations of the working group have been

\footnotetext{
83 I995 Agreement on straddling and highly migratory fish stocks.

${ }^{84}$ For example deep sea fisheries, bycatches and discards.

85 On the general topic of marine biodiversity protection, M.C. Ribeiro, 'A protecção da biodiversidade marinha: importancia do poder do Estado na prossecução deste «interesse geral», in J. Jorge Urbina \& M.T. Ponte Iglesias (Coord.), Protección de intereses colectivos en el Derecho del Mar y cooperación internacional (Iustel, Madrid, 20I2) 25-62.

86 Resolution A/RES/59/24, $\$ 73$.
} 
endorsed, without a vote, by the General Assembly on I9 June 2015 under Resolution A/RES/69/292 Development of an international legally-binding instrument under the United Nations Convention on the Law of the Sea on the conservation and sustainable use of marine biological diversity of areas beyond national jurisdiction. ${ }^{87}$ In fine, nothing was decided and the recommendations of the working group, as approved by the General Assembly, can be considered a diplomatic victory both by the pros and cons, states favorable to a new agreement and so-called "unconvinced" countries according to UN official vocabulary.

The Preparatory Committee (Prep Com) began its work in spring 2016.8 According to its mandate, Prep Com I has worked to make substantive recommendations on the elements of a draft agreement; the scope of an international legally binding instrument and its relationship with other instruments and bodies were considered, but principles were also discussed in particular the applicability of the principle of common heritage of mankind. The exchanges then focused on the set of issues identified in 2008 and considered as a package in 20Ir: marine genetic resources (status, definitions, access, benefit-sharing, intellectual property rights (IPRs) and institutional matters), area-based management tools including marine protected areas (definitions, objectives and principles, criteria, governance, institutional mechanisms, and links with regional approaches), environmental impact assessments (general concepts, definitions, thresholds, governance, transparency, and monitoring), capacity building and technology transfer (different approaches, specific capacity-building measures, institutional mechanisms, including a clearinghouse mechanism and a fund), institutional aspects (dispute settlement, responsibility and liability). On all these issues, the discussions have revealed significant differences of opinion, as to the legal regime likely to be adopted in the future.

The second session of the Prep Com (Prep Com 2) met a few months later, in the summer of 2016 , to work on the basis of the achievements made by Prep Com I and with the objective of summiting a compilation of proposals to Prep Com $3{ }^{89}$ The four issues included in the package were discussed again: marine genetic resources, in terms of definition of MGRs, including the possible inclusion of derivatives, data (in silico), ${ }^{90}$ and fish,,$^{9 \mathrm{I}}$ approaches, access and benefit-sharing (monetary and nonmonetary benefits, traditional knowledge, contributions to conservation and sustainable use), and intellectual property rights (IPRs); area-based management tools, with discussions focused on

87 Resolution A/RES/69/292.

88 The first session of the Preparatory Committee (Prep Com I) convened from 28 March to 8 April 2016; cf. Earth Negotiations Bulletin, Summary of the first session of the Preparatory Committee on marine biodiversity of areas beyond national jurisdiction: 28 March - 8 April 2016, International Institute for Sustainable Development (IISD), Vol. 25 No. Io6, Monday, II April 2016.

89 Prep Com 2 convened from 26 August to 9 September 2016; cf. Earth Negotiations Bulletin, Summary of the second session of the Preparatory Committee on marine biodiversity of areas beyond national jurisdiction: 26 August - 9 September 2016, International Institute for Sustainable Development (IISD), Vol. 25 No. II8, Monday, I2 September 2016.

90 The International Union for Conservation of Nature (IUCN) proposed to define resources in silico as "data containing DNA, RNA, proteins or enzymes"; Earth Negotiations Bulletin, Vol. 25 No. II8 aforementioned, at 3.

9r The new actuality of fisheries issue is related to the problematic of the legal regime likely to be applicable to fish; indeed, some States considered that it should be different, depending on whether fish is traditionally used as food or as a MGR. 
definitions (MPAs and marine spatial planning - MSP), approaches and governance; environmental impact assessments, in terms of definition and approaches, transboundary EIAs (TEIAs), thresholds, strategic environmental assessments (SEAs), institutional arrangements and existing instruments; capacity building and technology transfer, with exchanges focused on differentiated and common approaches, institutional mechanisms and funding. But the discussions also focused on cross-cutting issues, such as objectives, principles, scope, relationships with other instruments, in particular with LOSC, institutional arrangements, responsibility and liability, dispute settlement and final clauses. Finally, it was decided to draw up a report on possible areas of convergence and issues for further discussion, in order to prepare Prep Com 3 to be held in spring 2017.92 The Prep Com is expected to finish its work by the end of the year, and this undoubtedly complicates the challenges of negotiation.

\section{(ii) Challenges of Negotiation}

BBNJ is a real challenge for the future of the Law of the Sea, in particular in terms of sustainable development.93 $\mathrm{A}$ twofold approach is needed in order to perfectly understand the real issues of these negotiations. On the one side, the negotiation encompasses environmental concerns devoted to the preservation of high seas biodiversity, such as marine protected areas and environmental impact assessments. On the other side, it focuses on development issues, in relation with marine scientific research and marine genetic resources, especially as regards access to genetic resources and fair and equitable sharing of benefits. Taking into consideration that developed countries are a priori more interested in environmental aspects and developing countries in development promises, the challenge is to strike a real balance in terms of sustainable development, a fortiori in the legal context of a package that recalls in fact a package deal approach to negotiations.

Notwithstanding, a realistic approach is needed in order to take into consideration that environmental concerns are very often used as pretexts, especially by developed countries, to achieve other objectives. Large marine protected areas, for example, are currently called for by environmental NGOs and the Charitable Trusts that fund them, ${ }^{4}$ but they may be actually less justified in terms of biodiversity than of geopolitics,95 as evidenced by the strategy of the United States in the Pacific

92 The third session of the Prep Com is convened from 27 March to 7 April 2017.

93 Cf. F.M. Armas Pfirter, 'The Management of Seabed Living Resources in "the Area" under UNCLOS', II Revista Electrónica de Estudios Internacionales (2006); R. Rayfuse \& R.M. Warner, 'Securing a sustainable future for the oceans beyond national jurisdiction: the legal basis for an integrated cross-sectoral regime for high seas governance for the $2 \mathrm{I}^{\text {st }}$ century', The International Journal of Marine and Coastal Law (2008) 399-42I; T. Scovazzi, 'Negotiating Conservation and Sustainable Use of Marine Biological Diversity in Areas Beyond National Jurisdiction: Prospects and Challenges', The Italian Yearbook of International Law (2015) 6I-93; 'The Exploitation of Marine Genetic Resources in Areas Beyond National Jurisdiction', in G. Andreone (Ed.), Jurisdiction and Control at Sea. Some environmental and security issues, MARSAFENET (Giannini Editore, 20I4) 37-54, or S. Doumbé-Billé \& J-M. Thouvenin (Dir.), Mélanges en l'bonneur du Professeur Habib Slim, Ombres et lumières du droit international (Pédone, Paris, 2016) 175-190; Y. Tanaka, 'Reflections on the Conservation and Sustainable Use of Genetic Resources in the Deep Seabed Beyond the Limits of National Jurisdiction', Ocean Development $\mathfrak{o}$ International Law (2008) I29-I49 [DOI: I0.I080/00908320802013719].

94 Cf. the very well documented report, Y. Giron \& A. Le Sann, Blue Charity Business - la réforme des pêches européennes - premier panorama - 2000 à 20II, Pêche et développement 20I2; and also documents presented during the conference of Yan Giron, Vers une privatisation des océans?, Lorient Maison de la mer, 8 décembre 2014.

95 F. Féral \& B. Salvat (Dir.), Gouvernance, enjeux et mondialisation des grandes aires marines protégées (L’Harmattan, Paris, 20I4); F. Féral, 'L'extension récente de la taille des aires marines protégées : une progression des surfaces inversement 
Ocean, ${ }^{96}$ and the stratagem used by the United Kingdom in the Chagos Archipelago which is totally at the opposite of sustainable development principles.

Given the difficulties of enforcement, and the limited use of MPAs in jurisdictional waters and on the high seas, in both regions where there is an indisputable legal basis to their proclamation, in the Mediterranean ${ }^{97}$ and the Antarctic, ${ }^{98}$ it is evident that the issue is above all political and economic.

There is no coincidence that unconvinced states include United States, Russia, Japan, Canada, South Korea, developed countries where bioprospecting is an industrial reality. Conversely, developing states are globally favorable to a multilateral agreement, even though it is also interesting to note that the Group 77/China was progressively losing its coherence, due to the fact that some members have greater stakes than others.

In order not to be deceived by the future, it can also be useful to remember some lessons learned, ${ }^{99}$ in particular from the Third Conference, taking into consideration the fate of the concept of common heritage of mankind proposed by Arvid Pardo fifty years ago, ${ }^{100}$ especially after the adoption of the Implementation Agreement of $1994,{ }^{\text {Ior }}$ and taking into consideration the current prevailing approach on the seabed and subsoil.

proportionnelle à leur normativité, VertigO - la revue électronique en sciences de l'environnement, Hors-série 9, juillet 20II, Gestion durable des zones côtières et marines : nouveaux discours, nouvelles durabilités, nouvelles frontières [DOI: I0.4000/vertigo.I0998]; Y. Giron, 'The other side of large-scale, no-take, marine protected areas in the Pacific Ocean', in E. Fache \& S. Pauwels (Eds.), Fisheries in the Pacific The Challenges of Governance and Sustainability (Pacific-Credo Publications, 2016) 77-II7; P. Leenhardt et al., 'The rise of large-scale marine protected areas: Conservation or geopolitics?', Ocean $\mathfrak{G}$ Coastal Management (2013) II2-II8; S. Lelong, V. du Castel, Y. Giron, 'La croissance bleue. Puissances publiques versus puissances privées', Diploweb.com La Revue géopolitique, mardi is janvier 2016.

${ }_{96}$ As evidenced by the network of territorial influence into Pacific maritime areas, developed in particular via the Conservation Trusts formula, the twinning of MPAs, and the involvement of American territories (Guam, Northern Mariana Islands) in initiatives such as the Micronesia Challenge; this is part of the strategy used by the United States in order to assert their presence in front of Chinese positions, in the vicinity of the Russian zone of influence, and even to be able to interfere more or less discreetly in the French Pacific territories.

${ }_{97}$ In the framework of the Barcelona System, there is only one MPA incorporating high seas waters, with the legal status of Specially Protected Area of Mediterranean Importance (SPAMI), the Pelagos Sanctuary, established in 1999 by an international agreement between France, Italy and Monaco; all attempts to promote the development of a network of MPAs and other projects, such as the Franco-Spanish project in the Gulf of Lions, have failed. Cf. N. Ros, 'Environmental protection of the Mediterranean Sea', II Revista de Estudios Jurídicos (20II) 95-I27; 'Régimes juridiques et gouvernance internationale de la mer Méditerranée', in S. Doumbé-Billé \& J-M. Thouvenin (Dir.), Mélanges en l'bonneur du Professeur Habib Slim, Ombres et lumières du droit international (Pédone, Paris, 2016) 205-231.

${ }_{98}$ Within the Commission for the Conservation of Antarctic Marine Living Resources (CCAMLR), a MPA in the Ross Sea could finally be established on 28 October 2016, after five years of veto from China and then Russia; cf. K.N. Scott, 'Protecting the Last Ocean: the Proposed Ross Sea MPA. Prospects and Progress', in G. Andreone (Ed.), Jurisdiction and Control at Sea. Some environmental and security issues, MARSAFENET (Giannini Editore, 2014) 79-90.

99 N. Ros, 'Procesos convencionales del Derecho del Mar: Lecciones aprendidas', in J.M. Sobrino Heredia (Coord.), La toma de decisiones en el ámbito marítimo: Su repercusión en la cooperación internacional y en la situación de las gentes del mar (Editorial Bomarzo, Albacete, 2016) 26I-277.

${ }_{100}$ United Nations General Assembly, Twenty-Second Session, Official Records, First Committee, Agenda Item 92, Examination of the question of the reservation exclusively for peaceful purposes of the sea-bed and the ocean floor, and the subsoil thereof, underlying the bigh seas beyond the limits of present national jurisdiction, and use of their resources in the interests of mankind, Documents $\mathrm{A} / \mathrm{CI}_{\mathrm{I}} / \mathrm{I5} 15$ and 1516.

ror 1994 Agreement relating to the Implementation of Part XI of UNCLOS. 
(2) On the Seabed and Subsoil

In the International Seabed Area (b), the achievement of the legal regime is still underway, but on the continental shelf, offshore exploitation (a) is already a reality and a challenge for sustainable development.

\section{(a) On the Continental Shelf: Offshore Exploitation}

From the vantage point of International Law, the weak legal framework (i) applicable to offshore exploitation imposes a need for governance (ii), in order to strike a balance respectful of sustainable development objectives.

\section{(i) Weak Legal Framework}

At the universal level, there is no convention specially dedicated to offshore activities; besides the IMO Convention on Oil Pollution Preparedness, Response and Cooperation (OPRC), ${ }^{\mathrm{IO}}$ obviously more focused on ships than on platforms, the only legal framework is defined under LOSC, with general principles, in terms of maritime areas and by reference to the rights and obligations of the coastal state..$^{103}$

In a sustainable development perspective, the continental shelf is a real challenge. Indeed, offshore activities are very lucrative economic activities, which can be economically and socially vital. In order to achieve economic development the continental shelf is an essential asset, both for developed and developing states, because its exploitation can provide incomes and jobs, but also independence in terms of energy. It explains why the establishment of the outer limits of the continental shelf beyond 200 nautical miles, and the submissions to the Commission on the Limits of the Continental Shelf, are also a great challenge in terms of future development. ${ }^{\text {IO4 }}$

But offshore operations, including oil and gas, and other mining activities, involve a great potential of risks to the marine environment, especially because of the current use of deep and ultra-deep technologies, which are not only very expensive but also very dangerous and risky; before the dramatic accident occurred in April 20I0, the Deepwater Horizon platform had established a depth

${ }_{102}$ OPRC was adopted in 1999 and entered into force in 1995.

${ }^{103}$ In particular, Article 208 Pollution from seabed activities subject to national jurisdiction and Article 2 I4 Enforcement with respect to pollution from seabed activities.

ro4 INDEMER, Le plateau continental étendu aux termes de la Convention des Nations Unies sur le droit de la mer du Io décembre 1982. Optimisation de la demande, Académie de la Mer (Pédone, Paris, 2004); S.V. Suarez, The Outer Limits of the Continental Shelf. Legal Aspects of their Establishment, Beiträge zum ausländischen öffentlichen Recht und Völkerrecht, Band 199 (Springer 2008); T. Treves, 'La limite extérieure du plateau continental : Evolution récente de la pratique', Annuaire français de droit international (1989) 724-735 [DOI: I0.3406/afdi.1989.2929]. The challenges are also important a contrario, because the outer limits of the continental shelves will be those of the International Seabed Area, and of the Common Heritage of Mankind; cf. A. Chircop, 'Managing Adjacency: Some Legal Aspects of the Relationship Between the Extended Continental Shelf and the International Seabed Area', Ocean Development o $\mathcal{O}$ International Law (20II) $307-316$ [DOI: I0.1080/00908320.2011.619364]; E. Franckx, 'The International Seabed Authority and the Common Heritage of Mankind: The Need for States to Establish the Outer Limits of their Continental Shelf, The International Journal of Marine and Coastal Law (2010) 543-567 [DOI: I0.1163/157180810X525377]; J. Yu \& W. Ji-Lu, The Outer Continental Shelf of Coastal States and the Common Heritage of Mankind, Ocean Development of International Law (20II) 3I7-328 [DOI: I0.1080/00908320.2011.619366]. 
record, in 2009, in the same Gulf of Mexico, with a drilling of more than Io $\mathrm{km} . .$.

Coastal states have the sovereign rights to exploit, but most of the time they cannot do it themselves and authorize foreign companies to do so. In terms of economic and sustainable development, it can be unproductive due to the legal or contractual conditions. Transnational contracts are often unbalanced and although the legislation, including some monetary and fiscal aspects, is adopted by the coastal state, it is evident that it can be influenced by offshore companies. If a so-called old developed democracy such as France authorizes offshore exploration and exploitation without any financial compensation since $19933^{\text {I05 }}$ it is obviously very difficult for developing countries to resist the strong lobby of the oil and gas industry.

In this context, obligations to protect and preserve the marine environment are usually considered obstacles to economic development, and states, both developed and developing, do not naturally tend to prioritize them, taking into consideration sustainable development requirements. ${ }^{\mathrm{I} 6}$ These are the reasons that impose a need for governance.

(ii) Need for Governance

Indeed, in this context, and given that states are reluctant to the adoption of a global and universal convention devoted to offshore activities, and including in particular responsibility and liability mechanisms, a governance framework, international or regional as a minimum, appears the best option in order to strike a balance between exploitation and protection, in a perspective of sustainable development.

To be realistic, regional cooperation, in particular in the framework of UNEP regional seas programme, is the most effective solution. Indeed, in the world, there are only two existing treaties especially devoted to offshore activities, and they were both adopted under UNEP regional seas systems. ${ }^{\mathrm{IO} 7}$ The first is the Protocol Concerning Marine Pollution Resulting from Exploration and Exploitation of the Continental Shelf, ${ }^{108}$ adopted on 29 March 1989 and entered into force on 17 February 1990, in the framework of the 1978 Kuwait Regional Convention for Cooperation on the Protection of the Marine Environment from Pollution, ${ }^{\text {109 }}$ in the ROPME (Regional Organization for the Protection of the Marine Environment) Sea Area, including the Persian Gulf and the Sea of Oman, a region where offshore issues are very important. ${ }^{\text {II }}$ The second is the Protocol for the

ros N. Ros, 'Au-delà de la borne 6o2: la frontière maritime entre l'Espagne et la France en mer Méditerranée', 4 Journal $d u$ Droit international Clunet (20I4), at IIO7-IIIo; 'La pollution résultant de l'exploitation du sol et du sous-sol: le cas du plateau continental', in Droit des sites et sols pollués. Bilans et perspectives (L'Harmattan, Paris, 20I7) forthcoming.

ro6 N. Ros, 'Quel régime juridique pour l'exploitation offshore en Méditerranée ?', Annuaire de Droit Maritime et Océanique (2015) 205-26I.

I07 In all other cases, states prefer non-binding instruments such as in the Arctic, OSPAR (North-East Atlantic), or West, Central and Southern Africa.

ro8 Protocol concerning marine pollution resulting from exploration and exploitation of the continental shelf.

Iog Kuwait Regional Convention for Cooperation on the Protection of the Marine Environment from Pollution, adopted on 24 April 1978 and entered into force on I July 1979.

Iо D. Momtaz, 'La protection de l'environnement des mers fermées et semi-fermées : le cas du Golfe persique', in N. Ros \& F. Galletti (Dir.), Le droit de la mer face aux "Méditerranées", Quelle contribution de la Méditerranée et des mers semifermées au droit international de la mer ?, Cahiers de l'Association internationale du Droit de la Mer 5 (Editoriale Scientifica, Napoli, 2016) I7I-I82. 
Protection of the Mediterranean Sea against Pollution Resulting from Exploration and Exploitation of the Continental Shelf and the Seabed and its Subsoil,, framework of the Barcelona System in the Mediterranean Sea, but entered into force only on 24 March 20II. ${ }^{\mathrm{II}}$ It is interesting to note that this delay is due to coastal states, especially member states of the European Union, because of the high level of requirements of the Protocol, in particular the compulsory insurance or other financial security to cover liability of the operator. As regards the EU, the Directive on safety of offshore oil and gas operations, adopted on I2 June $2013{ }^{\text {II }}$ has a limited spatial applicability and is a disappointment compared to the initially proposed regulation... ${ }^{\text {II }}$

In a perspective of sustainable development, offshore activities remain of great environmental and social concern. To improve environmental conditions and safety and health of workers, better governance is needed worldwide, to guarantee the financial responsibility of economic operators and prevent registrations of convenience, as in the case of Deepwater Horizon registered in the Marshall Islands... Obviously similar issues also exist in the International Seabed Area.

\section{(b) In the International Seabed Area}

The de facto revision of Part XI of LOSC devoted to the Area, resulting from the adoption of the 1994 Implementation Agreement, ${ }^{\mathrm{II}}$ has imposed a new economic approach (i) to seabed resources. In a

III Protocol for the Protection of the Mediterranean Sea against Pollution Resulting from Exploration and Exploitation of the Continental Shelf and the Seabed and its Subsoil.

Ir2 On this Protocol and related Mediterranean challenges, cf. E. Raftopoulos, 'Sustainable Governance of Offshore Oil and Gas Development in the Mediterranean: Revitalizing the Dormant Mediterranean Offshore Protocol', Thursday i9 August 20IO, MEPIELAN E-Bulletin; N. Ros, 'Exploration, Exploitation and Protection of the Mediterranean Continental Shelf, in C. Cinelli \& E.M. Vásquez Gómez (Ed.), Regional Strategies to Maritime Security: a Comparative Perspective, MARSAFENET (Tirant lo Blanch, Valencia, 20I4) IOI-I32; 'Quel régime juridique pour l'exploitation offshore en Méditerranée ?', Annuaire de Droit Maritime et Océanique (2015) 205-26r; 'Vers une gouvernance régionale de l'offshore en mer Méditerranée ?', in A. Del Vecchio \& F. Marrella (Dir.), International Law and Maritime Governance. Current Issues and Challenges for the Regional Economic Integration Organizations / Droit international et gouvernance maritime. Enjeux actuels et défis pour les organisations régionales d'intégration économique / Diritto Internazionale e Governance Marittima. Problemi Attuali e Sfide per le Organizzazioni di Integrazione Economica Regionale, Cahiers de l'Association internationale du Droit de la Mer 3 (Editoriale Scientifica, Napoli, 2016) 219-242.

Ir3 Directive 2013/30/EU of the European Parliament and of the Council of I2 June 2013 on safety of offshore oil and gas operations and amending Directive 2004/35/EC, OJ 20I3 Lr78/66-IO6; cf. J. Juste Ruiz, 'La directive européenne sur la sécurité des opérations pétrolières et gazières en mer', Revue Juridique de l'Environnement (20I4) 23-43.

${ }^{114}$ On Euro-Mediterranean aspects, N. Ros, 'Environmental Challenges of Offshore Activities in International and European Union Law', in A. Caligiuri (Ed.), Governance of the Adriatic and Ionian Marine Space, Final Publication MaReMaP-AIR, Cahiers de l'Association internationale du Droit de la Mer 4 (Editoriale Scientifica, Napoli, 2016) 203-220; 'Problems of Marine Pollution resulting from Offshore Activities according to International and European Union Law', in A. Caligiuri (Ed.), Offshore Oil and Gas Exploration and Exploitation in the Adriatic and Ionian Seas, MaReMaP-AIR (Editoriale Scientifica, Napoli, 2015) 34-42; 'La réglementation euro-méditerranéenne des activités offshore', in Diritto del Commercio Internazionale (2015) 93-136; L. Schiano di Pepe, 'Offshore oil and gas operations in the Mediterranean Sea: regulatory gaps, recent developments and future perspectives', in J. Juste Ruiz \& V. Bou Franch (Dir.), Derecho del Mar y Sostenibilidad ambiental en el Mediterráneo (Tirant lo Blanch, Valencia, 2014) 363-387.

IIs Cf. F.H. Paolillo, 'Cuestiones institucionales en el Acuerdo de 1994 relativo a la parte XI de a Convención sobre el Derecho del Mar', Estudios Internacionales (1995) 43I-449; J.A. Carrillo Salcedo, 'De la Déclaration de 1970 sur les Fonds marins et leur sous-sol à l'Accord relatif à l'application de la Partie XI de la Convention des Nations Unies sur le droit de la mer', in R. Casado Raigón \& G. Cataldi (Dir.), L'évolution et l'état actuel du droit international de la mer, Mélanges de droit de la mer offerts à Daniel Vignes (Bruylant, Bruxelles, 2009) 83-91; also the proceedings of the Symposion The Entry into Force of the Convention on the Law of the Sea: A Redistribution of Competences Between States and International Organisations 
perspective of sustainable development, environmental challenges (ii) are obviously also at stake under the jurisdiction of the International Seabed Authority.

\section{(i) New Economic Approach}

As of today, International Seabed Authority has issued the Mining Code, a set of three regulations on prospecting and exploration for polymetallic nodules ( $\mathrm{I} 3$ July 2000, updated on 25 July 20I3), ${ }^{\mathrm{II}}$ polymetallic sulphides (7 May 20IO) ${ }^{\mathrm{II} 7}$ and cobalt-rich ferromanganese crusts (27 July 20I2); ${ }^{: 18}$ meanwhile, it has also adopted recommendations for contractors. At the beginning of 20I7, the International Seabed Authority has signed fifteen-year contracts for exploration activities with twenty-six contractors sponsored by states parties; sixteen contracts are for exploration for polymetallic nodules, fifteen in the Clarion-Clipperton Fracture Zone and one in the Central Indian Ocean Basin; six contracts are for exploration for polymetallic sulphides in the South West Indian Ridge, Central Indian Ridge and the Mid-Atlantic Ridge, and four contracts for exploration for cobalt-rich crusts in the Western Pacific Ocean. ${ }^{\text {II }}$

Seven of these exploration contracts have already come to an end, but exploitation is not yet on the agenda and its economic dimension has changed a lot since the adoption of LOSC, in its real perception as in its imaginary dimension... The principle is still stated as under Article 136, "the Area and its resources are the common heritage of mankind", and consequently Article 140 provides that "activities in the Area shall [...] be carried out for the benefit of mankind as a whole [...] and taking into particular consideration the interests and needs of developing States". Although adopted before the official emergence of the concept, Part XI was the greatest sustainable development promise... But the 1994 Agreement, combined with the political and economic evolution, has converted the common heritage into a myth; ${ }^{\mathrm{I} 20}$ the existing legal regime is far below the Pardo proposal. ${ }^{\mathrm{I} 2}$ It seems

in Relation to the Management of the International Commons?, Heidelberg, January $26-28$, 1995, published in Zeitschrift für ausländisches öffentliches Recht und Völkerrecht - Heidelberg Journal of International Law (1995) 273-658.

${ }_{\text {II }}$ ISBA/Ig/A/9, Decision of the Assembly of the International Seabed Authority regarding the amendments to the Regulations on Prospecting and Exploration for Polymetallic Nodules in the Area; ISBA/Ig/C/r7, Decision of the Council of the International Seabed Authority relating to amendments to the Regulations on Prospecting and Exploration for Polymetallic Nodules in the Area and related matters.

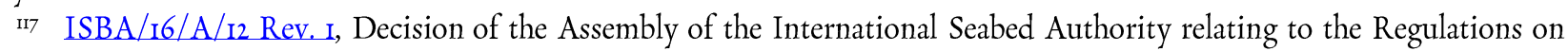
Prospecting and Exploration for Polymetallic Sulphides in the Area.

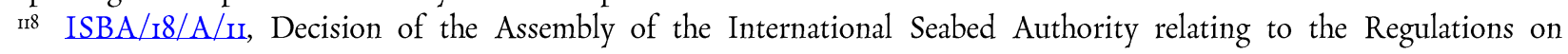
Prospecting and Exploration for Cobalt-rich Ferromanganese Crusts in the Area.

II9 Deep Seabed Minerals Contractors.

${ }^{220}$ On the initial concept, cf. A.Ch. Kiss, 'La notion de patrimoine commun de l'humanite', 175 Recueil des cours de l'Académie de droit international de La Haye (1982) 99-256; R. Wolfrum, 'The Principle of the Common Heritage of Mankind', Zeitschrift für ausländisches öffentliches Recht und Völkerrecht - Heidelberg Journal of International Law (1983) 312337; concerning its evolution, M. Bourrel, T. Thiele, D. Currie, 'The common of heritage of mankind as a means to assess and advance equity in deep sea mining', Marine Policy (2016) forthcoming; E. Guntrip, 'The Common Heritage of Mankind: an Adequate Regime for Managing the Deep Seabed?', Melbourne Journal of International Law (2003) 376-405; A. Jaeckel, K.M. Gjerde, J.A. Ardron, 'Conserving the common heritage of humankind - Options for the deepseabed mining regime', Marine Policy (2017) I50-I57; M.T. Ponte Iglesias, 'La zona internacional de los fondos marinos como patrimonio común de la humanidad: una aspiración truncada', Cursos de Derecho Internacional y Relaciones Internacionales de Vitoria-Gasteiz (Ponencias publicadas, Universidad del País Vasco, 1997) 177-205.

${ }_{22 r}$ J.A. Carrillo Salcedo, 'De la Déclaration de 1970 sur les Fonds marins et leur sous-sol à l'Accord relatif à l'application 
satisfactory for developed states, obviously representing most of the current contractors of the Authority. As for developing states, the benefits are more uncertain and, even taking into consideration their interests and needs, some risks exist as regards their international responsibility, a fortiori in the hypothesis of a sponsorship of convenience, as evidenced by the Advisory Opinion issued by ITLOS on I February 20II, as regards Responsibilities and obligations of States sponsoring persons and entities with respect to activities in the Area. ${ }^{\mathrm{I2}}$ Nevertheless, all states are concerned by the environmental challenges of the future exploitation of the Seabed Area and its mineral resources.

\section{(ii) Environmental Challenges}

In the perspective of a future exploitation, another objective of sustainable development is the Protection of the marine environment, a conventional obligation under Article 145 of LOSC: "Necessary measures shall be taken [...] to ensure effective protection for the marine environment from harmful effects which may arise from [...] activities" in the Area. The International Seabed Authority has the responsibility to establish international rules, regulations and procedures to prevent, reduce and control pollution of the marine environment from mining activities, especially exploitation of seabed non-living resources, and to protect and conserve the great but fragile biodiversity of the Area, preventing damage to specialized and quite pristine ecosystems, both flora and fauna.

In 20I2, the Council of the Authority adopted an Environmental Management Plan (EMP) for the Clarion-Clipperton Zone, in the Pacific Ocean, to be implemented on a provisional basis over an initial three-year period:;23 it includes the establishment of a network of nine areas of particular environmental interest intended to protect the biodiversity and ecosystem structure and functioning of the Zone from the potential impacts of seabed mining. ${ }^{124}$ Nevertheless, these areas are situated at the periphery but within the limits of the current exploration zone; ${ }^{\mathrm{I} 25}$ according to specialists they will be necessarily impacted by deep seabed mining. Furthermore, they are the only examples of environmental protection, in the only case of polymetallic nodules exploration; so far, nothing similar

de la Partie XI de la Convention des Nations Unies sur le droit de la mer', in R. Casado Raigón \& G. Cataldi (Dir.), L'évolution et l'état actuel du droit international de la mer, Mélanges de droit de la mer offerts à Daniel Vignes (Bruylant, Bruxelles, 2009) 83-9I.

r22 ITLOS, Advisory Opinion of I February 20rI. Cf. J.N. Guerrero Peniche, 'La opinión consultiva del Tribunal Internacional del Derecho del Mar: Aspectos relativos a la determinación del vínculo efectivo entre los Estados y las personas jurídicas a las que patrocinan para llevar a cabo actividades en la Zona', Anuario Colombiano de Derecho Internacional (20I2) I53-2I8; M.T. Ponte Iglesias, 'La prospección y exploración de la zona internacional de los fondos marinos y oceánicos de una manera ambientalmente responsable. Aportes de la primera opinión consultiva de la Sala de Controversias de Fondos Marinos', in J. Jorge Urbina \& M.T. Ponte Iglesias (Coord.), Protección de intereses colectivos en el Derecho del Mar y cooperación internacional (Iustel, Madrid, 2012) 63-107; and with a more general point of view, J-P. Beurier, 'L'autorité internationale des fonds marins, l'environnement et le juge', VertigO - la revue électronique en sciences de l'environnement, Hors-série 22, septembre 20I5, La représentation de la nature devant le juge : approches comparative et prospective [DOI: I0.4000/vertigo.16169].

${ }^{\mathrm{r} 23} \mathrm{ISBA} / \mathrm{I} / \mathrm{C} / 22$, Decision of the Council relating to an environmental management plan for the Clarion-Clipperton Zone; ISBA/r7/LTC/7, Environmental Management Plan for the Clarion-Clipperton Zone.

${ }^{124}$ M. Lodge, 'Some Legal and Policy Considerations Relating to the Establishment of a Representative Network of Protected Areas in the Clarion-Clipperton Zone', The International Journal of Marine and Coastal Law (20II) 463-480; M. Lodge et al., 'Seabed mining: International Seabed Authority environmental management plan for the Clarion-Clipperton Zone. A partnership approach', Marine Policy (2014) 66-72.

${ } 25$ Exploration Areas. 
is planned for polymetallic sulphides and cobalt-rich ferromanganese crusts.

When exploitation will begin, it will be even more necessary to reach a balance, in order not to destroy once and for all the treasures of this unknown biodiversity. Otherwise, it will be hardly possible to refer to sustainable development, given the very slow development pace of such ecosystems, irremediably lost for future generations...

\section{CONCLUSION}

After the CoP 2I of United Nations Framework Convention on Climate Change, convened in Paris from 30 November to II December 2015 and concluded by the adoption of the Paris Agreement ${ }^{126}$ - a diplomatic success but a climatic failure given its material soft law character- entered into force on 4 November 2016, climate challenges linking sustainable development and Law of the Sea cannot be ignored anymore, even though the issue of oceans and seas has so far been addressed only marginally and in no way from a legal perspective.

Indeed, climate change and related effects on the oceans, especially warming, sea level rise and ocean acidification are inevitably expected to continue in the future, with substantial risks to marine environment, especially polar ecosystems and coral reefs, and potentially detrimental consequences for marine activities, primarily fisheries. Ocean-related sectors, for example shipping and fishing, have worked for a number of years towards developing sectoral energy-efficiency measures with a view to reducing their greenhouse gas emissions, particularly following FAO and IMO initiatives. The 70th session of the Marine Environment Protection Committee (MEPC) of the International Maritime Organization, convened in London from 24 to 28 October 2016, precisely adopted a set of dedicated measures, such as mandatory data collection system for fuel oil consumption and a roadmap for reducing greenhouse gas (GHG) emissions. ${ }^{127}$ But the effects and risks associated with climate change remain a great concern, especially in low-lying coastal zones, Small Island Developing States and other small islands. In addition to human and environmental impacts, the loss of land along the coastlines or the disappearance of an island could have serious legal consequences, for example regarding the definition of the baselines used to measure maritime areas, and indirectly to delimit them, but also in terms of existence and viability, especially in the case of a small island state...

In this context, it is important to consider how the relevant policy and regulatory frameworks interlink, even if conventional provisions related to this approach are really very few... In the case of LOSC, only three articles can be mentioned in this perspective and in close connection with sustainable development imperatives and requirements: Article 192 stating as a General obligation that "States have the obligation to protect and preserve the marine Environment", Article $2 \mathrm{I2}$ dealing with Pollution from or through the atmosphere, and Article 222 dedicated to Enforcement with respect to pollution from or through the atmosphere. The 1992 United Nations Framework Convention on Climate Change is applicable insofar Article 2 gives a very broad definition of the objective of the

${ }^{126}$ Paris Agreement, United Nations, 2015.

I27 IMO, 7oth session of the Marine Environment Protection Committee (MEPC). 
Convention, and any related legal instruments that the Conference of the Parties may adopt, i.e. "to achieve [...] stabilization of greenhouse gas concentrations in the atmosphere at a level that would prevent dangerous anthropogenic interference with the climate system"; obviously this requirement also applies to oceans and seas. Last text regulates marine geo-engineering which are methods that aim to deliberately alter natural systems to counter climate change, including ocean fertilization, defined as "any activity undertaken by humans with the principal intention of stimulating primary productivity in the oceans", ${ }^{128}$ these are the 2013 amendments to the 1996 Protocol to the 1972 London Convention on the Prevention of Marine Pollution by Dumping of Wastes and Other Matter. These new provisions will enter into force sixty days after two-thirds of the Contracting Parties have deposited an instrument of acceptance with the IMO; they prohibit all ocean fertilization activities, other than those specifically referred to in the new annex 4 , that is to say, unless the proposed activity is assessed as constituting legitimate scientific research.

Climate change is expected to become one of the key points of interaction between sustainable development and Law of the Sea; and it would be an error to continue to believe that only Small Island Developing States will be affected by this dialectic.

${ }_{\text {I28 }}$ Under new annex 4 on marine geoengineering, "Ocean fertilization does not include conventional aquaculture, nor mariculture, nor the creation of artificial reefs". 